\title{
Sources, turnover and bioavailability of dissolved organic nitrogen (DON) in the Colne estuary, UK
}

\author{
E. C. Agedah ${ }^{1,2}$, H. E. Binalaiyifa ${ }^{1}$, A. S. Ball ${ }^{1,3}$, D. B. Nedwell ${ }^{1, *}$ \\ ${ }^{1}$ Department of Biological Sciences, University of Essex, Colchester CO4 3SQ, UK \\ ${ }^{2}$ Present address: Department of Biology, Niger Delta University, Wilberforce Island, Bayelsa State, Nigeria \\ ${ }^{3}$ Present address: Flinders University, School of Biological Sciences, GPO Box 2100, Adelaide, South Australia 5001, Australia
}

\begin{abstract}
The significance of dissolved organic nitrogen (DON) as a eutrophication pressure in the Colne estuary, eastern England, was studied. DON comprised a significant proportion (19\%) of the annual total dissolved $\mathrm{N}$ load to the Colne estuary. DON concentrations in the upper Colne estuary correlated seasonally with river flow; in contrast, DON inputs from the Colchester sewage treatment works (STW) were constant seasonally, and during summer exceeded the input of DON from the river. Bioassays showed that only 2.2 to $5.2 \%$ of DON were bioavailable at any given time, and bioavailability was significantly lower in STW DON than in fluvial DON. Degradation of DON within the estuarine water column followed first-order kinetics and was very slow (mean $0.4 \%$ of DON removed $\mathrm{d}^{-1}$ ) although removal by the bottom sediments was faster (mean $3 \% \mathrm{DON} \mathrm{d}^{-1}$ ). The low bioavailability and slow breakdown rate of DON, compared to the typical freshwater flushing time of water in the estuary, meant that the DON load, though considerable, did not represent a significant eutrophication pressure within the estuary. Most DON was degraded outside the estuary in the coastal zone.
\end{abstract}

KEY WORDS: Dissolved organic nitrogen $\cdot$ DON $\cdot$ Bioavailability $\cdot$ Estuarine N loads Resale or republication not permitted without written consent of the publisher

\section{INTRODUCTION}

Nitrogen $(\mathrm{N})$ is a major nutrient limiting primary production in marine and some estuarine environments. Anthropogenic inputs of $\mathrm{N}$ to the environment, both from fertiliser run-off and from inputs of treated and untreated sewage effluents, now exceed the natural inputs to the biological N cycle (Vitousek et al. 1997, Hessen 1999). Increased inputs of inorganic $N$ to catchments, estuaries and coastal waters have resulted in nutrient enrichment and eutrophication (De Jonge et al. 2002). Dissolved inorganic N (DIN) has been considered to be the most significant source of biologically available $\mathrm{N}$, but this viewpoint has been revised with the realisation that dissolved organic $\mathrm{N}$ (DON) in some estuaries represents as much as $90 \%$ of the total dissolved N (Seitzinger \& Sander 1997), and that even high molecular weight DON can be biologically avail- able to both primary producers and consumers such as bacteria (Stepanauskas et al. 1999, Veuger et al. 2004). The $\mathrm{N}$ load from a catchment tends to increase with anthropogenic impact, and also varies with land use (Perakis \& Hedin 2002, Stedmon et al. 2006). DON tends to represent a relatively high proportion of the total $\mathrm{N}$ load from pristine catchments, but decreases as a proportion as the total $\mathrm{N}$ load increases (Nedwell et al. 1999). However, in anthropogenically impacted catchments, despite comprising a lower percentage of the total $\mathrm{N}$ load, anthropogenic sources of DON may be several-fold higher than the natural DON background (Howarth 2004).

The present work was undertaken to determine the magnitude, sources, seasonal variation and biological significance of DON inputs to the Colne estuary on the east coast of England, where $\mathrm{N}$ loads are high due to both run-off of $\mathrm{N}$ from arable land and inputs 
from sewage treatment works serving relatively high human population densities (Nedwell et al. 2002). We wished to test the hypothesis that DON is a significant part of the total $\mathrm{N}$ load to the Colne estuary, and that it exerts eutrophication pressure within the estuary. Furthermore, the work indicates the impact of the DON load on the associated coastal zone.

\section{MATERIALS AND METHODS}

Analysis of DON was achieved by a modification of the Kjeldahl digestion following the method of Fraga (1959), improved by Doval et al. (1997). It has the advantage that it removes background DIN (as nitrate, nitrite or ammonium) before converting DON to ammonium, which can then be measured. It is therefore a direct measure of DON rather than measuring DON by the difference between total $\mathrm{N}$ before and after digestion. Preliminary work confirmed that $>98 \%$ of background ammonium, nitrate and nitrite were removed by the technique (Agedah 2005) and that digestion and recovery of $300 \mu \mathrm{M}$ standards each of arginine, glycine, proline and urea were $>98 \%$, although recovery of nicotinic acid was low, as reported previously (Doval 1997).

Measurements of DIN and DON in the Colne estuary. Initially, samples were taken at monthly intervals at high tide at 11 sites along the complete salinity gradients of the Colne estuary (Fig. 1) in late summer from August to October 2001. Subsequently, a more extensive sampling programme was carried out at monthly

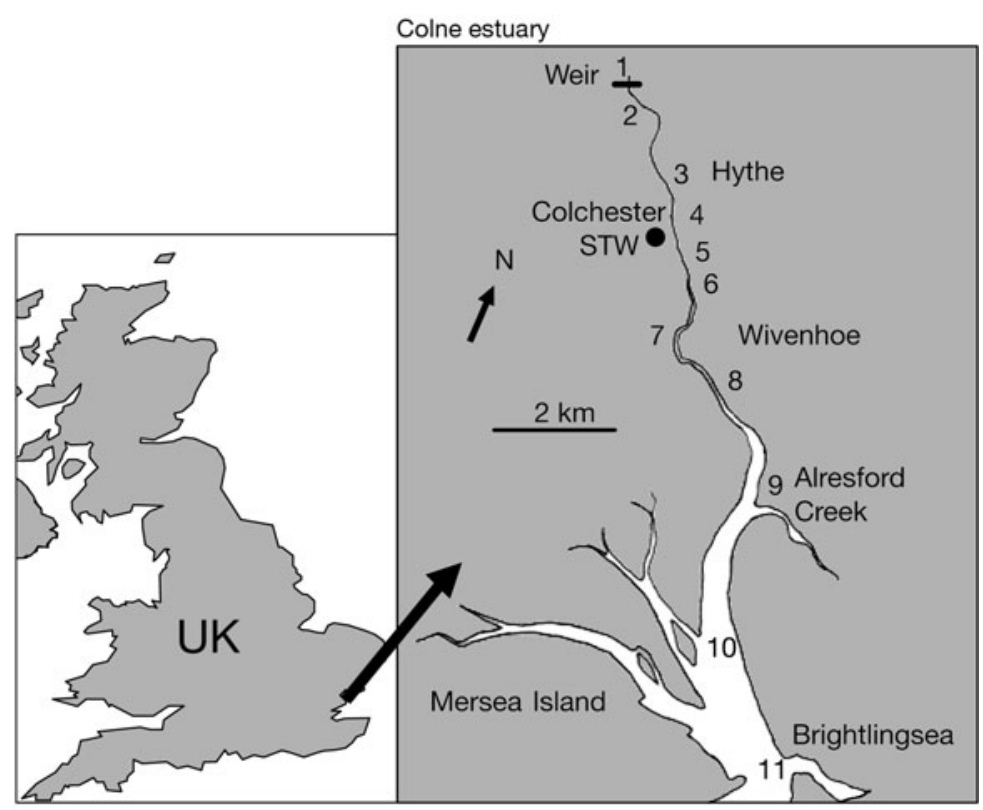

Fig. 1. Colne estuary, showing sampling sites. STW: sewage treatment works intervals in the Colne estuary from July 2002 to July 2003. At each sampling point, triplicate samples of water were taken in clean glass bottles and brought to the laboratory within $2 \mathrm{~h}$ of collection. Salinity was measured with an optical refractometer (model 10419, Reichert-Jung, Cambridge Instruments). On return to the laboratory, samples were filtered through glass fibre filters to remove particulates (Whatman GF/F), precombusted at $450^{\circ} \mathrm{C}$ for $24 \mathrm{~h}$ to remove any contaminant organic nitrogen $(\mathrm{ON})$ in the filters, rinsed 3 times with ultra high purity (UHP) water, and then dried (Ward \& Wetzel 1984, Buffan et al. 2001). Filters were stored in a freezer at $-20^{\circ} \mathrm{C}$ prior to use. The filtrates were then used to analyse DIN (nitrate, nitrite and ammonium) and DON.

DIN and DON loads from the River Colne. Triplicate samples of river water were taken at monthly intervals from July 2002 to June 2003, just above the upper tidal limit of the estuary at East Hill Weir (national grid reference TM008253). Samples were analysed colorimetrically for nitrate, nitrite (Strickland \& Parsons 1972, Collos et al. 1992) and ammonium (Harwood \& Kuhn 1970, Krom 1980) by a segmented flow analyser (Skalar SANplus, Scalar Analytical) and for DON. The water flow data for the Lexden gauging station (reference number 37005) on the River Colne upstream of Colchester were obtained from the National River Flow Archive (www.nwl.ac.uk/ih/nrfa).

DIN and DON loads from sewage treatment works (STW). Triplicate samples of effluent from the discharge pipe from the Colchester STW were collected monthly from June to September 2003, and in February and October 2004. DIN and DON were analysed as described above. The mean monthly discharge flow rates from the Colchester STW were provided by Anglian Water PLC.

DON loads from estuarine sediments. The DON:salinity plots for data from water samples taken along the Colne estuary (see 'Results') showed that generally DIN decreased more rapidly down the estuary than DON, suggesting either that DIN was removed more rapidly than DON or that there were other sources of DON along the estuary. Experiments were therefore set up to investigate whether there was exchange of DON between estuarine sediments and the water column, as suggested by other studies (Lomstein et al. 1998, Mortazavi et al. 2001, Sundbäck et al. 2004). Three sedimentwater exchange experiments were carried out, in January, April and June 2004. The first experiment was at the Hythe site only, which has the most organic sediments, and 
therefore where exchange of DON was most likely. Subsequent experiments were carried out with sediment from sites at the top (Hythe), middle (Wivenhoe) and bottom (Brightlingsea) of the estuary, covering the whole estuarine gradient.

At high tide, water from each site was collected and returned to the laboratory, and maintained with aeration at in situ temperature with a heat exchange coil connected to a thermocirculator. At low tide, triplicate sediment cores about $20 \mathrm{~cm}$ deep were taken just below the low water mark with Perspex core tubes $(50 \mathrm{~cm} \times 8 \mathrm{~cm}$ internal diameter) at all 3 sites. The cores were immersed in a bath of site water, with 11 of site water above the sediment in each core, and aerated with humidified air to maintain air equilibration in the water. Triplicate control tubes each containing $1 \mathrm{l}$ of site water only were also set up for each site. The core tubes were then incubated in the dark for up to $6 \mathrm{~d}$. A sample $(50 \mathrm{ml})$ of the water in each core tube was taken initially $\left(\mathrm{t}_{0}\right)$ and at daily intervals, filtered through GF/F filters to remove particulates and then frozen for subsequent analyses of both DIN and DON.

DON concentration. Water samples for bioassays were filtered through precombusted and washed GF/F filters and then concentrated with a stirred cell ultrafiltration unit (YC, Amico). The Relative Molecular Mass $\left(\mathrm{M}_{\mathrm{r}}\right)$ generally used to concentrate DON has been 1 kDa (Benner et al. 1992, Amon\& Benner 1994), but we used a molecular weight cut-off of 500 Da to retain smaller $M_{r}$ DON while efficiently removing DIN, which would also include urea and very small DON molecules such as amino acids and small polypeptides. Ultrafiltration was at 3.7 bar pressure with air (BOC gases). An initial 11 of water was concentrated 10-fold to a final volume of $100 \mathrm{ml}$, and then $100 \mathrm{ml}$ UHP water were added and reconcentrated to $100 \mathrm{ml}$ to further remove residual DIN. All samples were ultrafiltered in a cold room at 4 to $5^{\circ} \mathrm{C}$ to avoid any degradation of DON. Concentrates were analysed for DIN and DON, and then stored in a freezer for the subsequent bioassay.

Bioavailability of DON. DON is a complex and variable mixture of different $\mathrm{N}$-containing organic molecules whose availability to microbial use varies. There is no way of linking bioavailability to any particular chemical characteristic of the components of DON, and bioavailability remains an operationallydefined term whose quantification depends to some extent upon the method selected. Most workers have taken a pragmatic approach and used some form of bioassay to assess DON bioavailability. For example, Seitzinger \& Sanders (1997) and others (Stepanauskas et al. 1999, Boyer et al. 2004) measured removal of DON and the growth of a natural mixed community of bacteria isolated from river water for bioassay. Such a mixed community is likely to be able to metabolise a wide variety of the DON compounds present, but, by definition, it is impossible to quantify or calibrate the growth response of such natural, but undefined, mixtures of microbial populations whose growth rates and growth yields will vary. Indeed, none of the above papers used standards such as ammonium to show whether the growth response of the mixed microbial communities to available $\mathrm{N}$ was consistent. We chose to use an approach (Nedwell et al. 1987) wherein a single metabolically versatile bioassay organism (Pseudomonas aeruginosa), which is able to metabolise a wide range of organic substrates, was used whose growth response to the presence of available DON could be quantified reproducibly.

A mineral salts medium (see Nedwell 1987) that supported the growth of Pseudomonas aeruginosa (NCIMB 8295) containing glucose $(1.4 \% \mathrm{w} / \mathrm{v})$ as the available organic substrate was used. For the bioassays, $\mathrm{N}$ was omitted from the culture and growth depended upon the amount of available $\mathrm{N}$ present in the DON fraction added. The inoculum was prepared from $P$. aeruginosa grown on nutrient agar for $24 \mathrm{~h}$ at $20^{\circ} \mathrm{C}$. A colony was then transferred aseptically into the complete mineral medium containing $\mathrm{N}$ as $\mathrm{NH}_{4}{ }^{+}$ and incubated at $20^{\circ} \mathrm{C}$ for $24 \mathrm{~h}$ in an orbital incubator. The cells were then centrifuged down twice and resuspended in $\mathrm{N}$-free mineral medium to remove residual $\mathrm{N}$, and $20 \mu \mathrm{l}$ of cell suspension were added per tube as the standard inoculum.

Assays were carried out with aliquots (49 ml) of Nfree medium in sterile conical flasks. Each flask was made up to $50 \mathrm{ml}$ with addition of either $1 \mathrm{ml}$ of DON concentrate (see below), or a known amount of available $\mathrm{N}$ as ammonium chloride for standards, or sterile $\mathrm{N}$-free medium for blanks (every treatment in triplicate). Each flask was inoculated with $20 \mu \mathrm{l}$ of inoculum and incubated on an orbital shaker at $20^{\circ} \mathrm{C}$. The amount of growth of Pseudomonas aeruginosa was measured by daily recording the optical density (OD) of the culture with a nephelometer (DS29 Digital Unigalvo, Diffusion Systems), and the maximum OD was recorded. Initially, a range of volumes of DON concentrate $(1,2,3,5,10 \mathrm{ml})$ was used in each assay flask to check what range gave linear turbidity results. Initial experiments showed that with larger volumes of DON concentrate (5 or $10 \mathrm{ml}$ flask $^{-1}$ ) in a bioassay there could be appreciable turbidity produced initially, apparently by precipitation from the DON concentrate. There was no precipitation with 1 or $2 \mathrm{ml}$ of concentrate, and biomass production was proportional to concentrate volume added. We used $1 \mathrm{ml}$ of concentrate in each assay flask thereafter.

To measure DON bioavailability from the river, samples of water (all in triplicates) were taken twice during 
January 2004 from the Hythe site. In addition, during March 2004, water samples were collected just above the tidal limit at the weir on 2 occasions, from the STW effluent on 3 occasions, and from the Hythe site on 2 occasions. The samples were concentrated, and the DON concentrate was used in the bioassays as described.

\section{RESULTS}

\section{Concentrations of DON in the Colne estuary}

Examples of the spatial distributions of DIN and DON concentrations and salinity along the estuary, and the percentage of DON in total dissolved $\mathrm{N}$ are shown in Fig. 2 for January and June (winter and summer examples). The DIN and DON concentrations decreased down the estuary as the loads from the freshwater end mixed with low nutrient coastal seawater. Linear regressions of either DIN or DON versus salinity (e.g. Fig. 3) gave statistically significant straight lines ( $p<0.05$ in all cases), indicating apparently conservative mixing through the Colne estuary. However, occasionally the measured river DON con- centration was less than the river end-member concentration derived from the regression of DON versus salinity, a peak of DON concentration occurring at salinities $\sim 5$ (see plot for nitrate, June, Fig. 3).

DON concentrations at the top of the estuary (Fig. 4) were relatively constant and high throughout the year (range 130 to $300 \mu \mathrm{M}$ ), and averaged $22 \%$ of the total dissolved N (TDN = DIN + DON) concentrations in the upper Colne. At the mouth of the estuary, DON and DIN varied seasonally, peaking during winter (Fig. 4). The percentage of DON in TDN varied along the estuary (Fig. 2), typically being $\sim 20 \%$ of TDN at the top of the estuary, but increasing to 60 to $70 \%$ of TDN in the summer at the mouth of the estuary where DIN concentrations were lower. Nitrate was the predominant form ( $>90 \%$ ) of DIN at the top of the estuary, and $\mathrm{NH}_{4}{ }^{+}$ was $<10 \%$ of DIN.

\section{Fluvial load}

Fig. 4 shows the mean monthly river flow (in $\mathrm{Ml} \mathrm{d}^{-1}$ ) for the Colne and the concentrations of DIN and DON in the river water. There was a distinct seasonal variation in flow, with a large increase in November

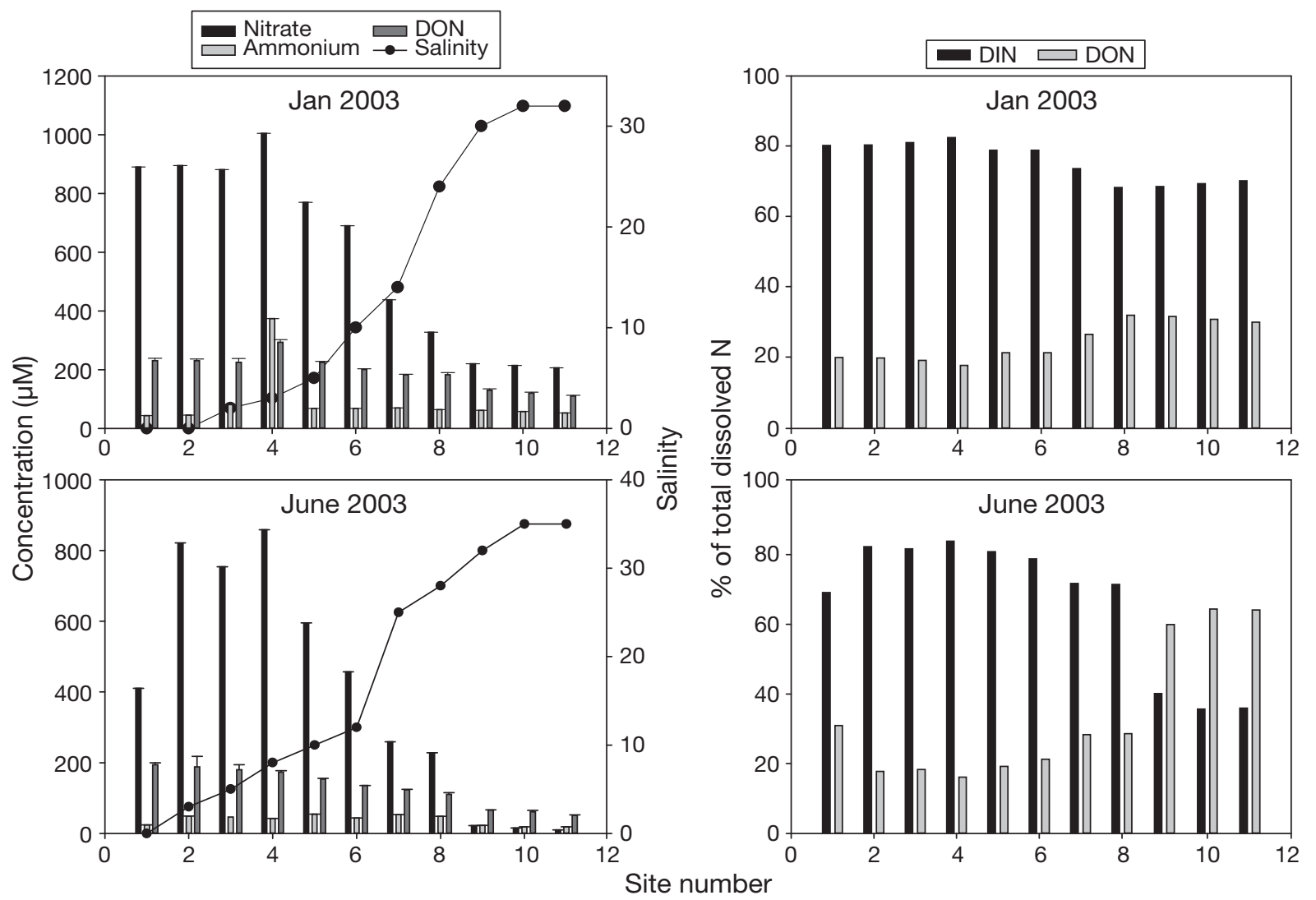

Fig. 2. Examples of DON and DIN concentrations and salinity along the Colne estuary, and percentages of DON and DIN (bars indicate $\mathrm{SE}, \mathrm{n}=3$ ) 

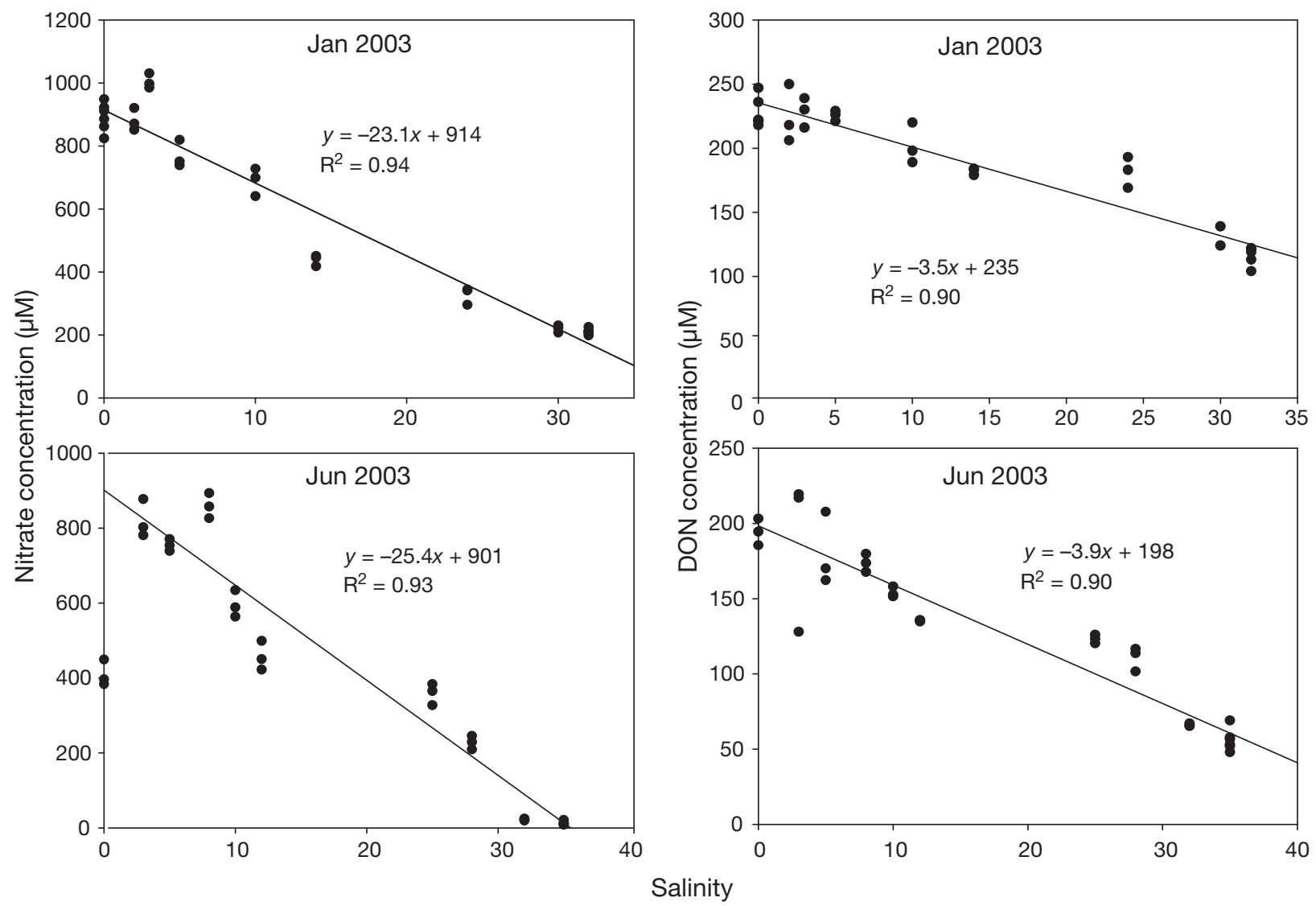

Fig. 3. DON:salinity and nitrate:salinity plots for January and June 2003

through February with winter rains. Nitrate, but not ammonium (data not shown), increased in concentration during this high flow period. In contrast, DON concentration in the river water showed at most a moderate increase during the high flow period. Plots of DON or nitrate concentrations (but not ammonium) versus river flow both gave significant linear regressions $(\mathrm{p}<$ 0.05), showing that their concentrations were related to river flow rate. The monthly load was calculated by multiplying the mean monthly flow and the monthly concentration, and scaling up to monthly rate. Summation of monthly loads gave annual fluvial load of DIN of 40.4 $\mathrm{Mmol} \mathrm{N} \mathrm{yr}^{-1}$, and 12.0 $\mathrm{Mmol} \mathrm{N} \mathrm{yr}^{-1}$ of DON over the period of study (Table 1 ).

Table 1. Annual loads ( $\mathrm{Mmol} \mathrm{N} \mathrm{yr}^{-1}$ ) and percentages of DON and DIN (nitrate + ammonium) loads from river and sewage treatment works (STW). Values in parentheses are percentages of each component from river or STW inputs

\begin{tabular}{|ccccc|}
\hline & $\begin{array}{c}\mathrm{NO}_{3}^{-} \\
\left(\mathrm{Mmol} \mathrm{N} \mathrm{yr}^{-1}\right)\end{array}$ & $\begin{array}{c}\mathrm{NH}_{4}{ }^{+} \\
\left(\mathrm{Mmol} \mathrm{N} \mathrm{yr}^{-1}\right)\end{array}$ & $\begin{array}{c}\mathrm{DON} \\
(\%)\end{array}$ & $\begin{array}{c}\text { Total N } \\
(\%)\end{array}$ \\
\hline River & $38.0(68)$ & $2.4(19)$ & $12.0(74)$ & $52.4(62)$ \\
STW & $17.5(32)$ & $10.2(81)$ & $4.3(32)$ & $32.0(38)$ \\
\hline
\end{tabular}

\section{STW load}

STW load was essentially constant throughout the year (Fig. 5), although there were slight increases in the mean monthly flow during January and February. The DIN and DON concentrations in the STW effluent did not vary significantly seasonally (mean \pm SD: nitrate $550 \pm 41 \mu \mathrm{M}$, ammonium $945 \pm 33 \mu \mathrm{M}$, DON 222 $\pm 7 \mu \mathrm{M})$. There were no significant relationships $(\mathrm{p}>$ 0.05) of either DIN or DON concentrations with STW flow rate. Total annual loads from the STW (Table 1) were 27.7 $\mathrm{Mmol} \mathrm{N} \mathrm{yr}^{-1} \mathrm{DIN}$, and 4.3 $\mathrm{Mmol} \mathrm{N} \mathrm{yr}^{-1} \mathrm{DON}$.

\section{Sediment-water exchange of DON}

The experiments during January, April and June 2004 showed that all sites along the Colne estuary experienced slow decreases in the DON concentrations in the water above the sediment cores over the course of $6 \mathrm{~d}$. Linear regressions of $\ln$ DON versus time for each site were significant $(p<0.001$ in all cases) and conformed to first-order kinetics (Table 2); that is, a constant proportion of the DON was removed $\mathrm{d}^{-1}$. The water-only controls showed that the rate of dark 


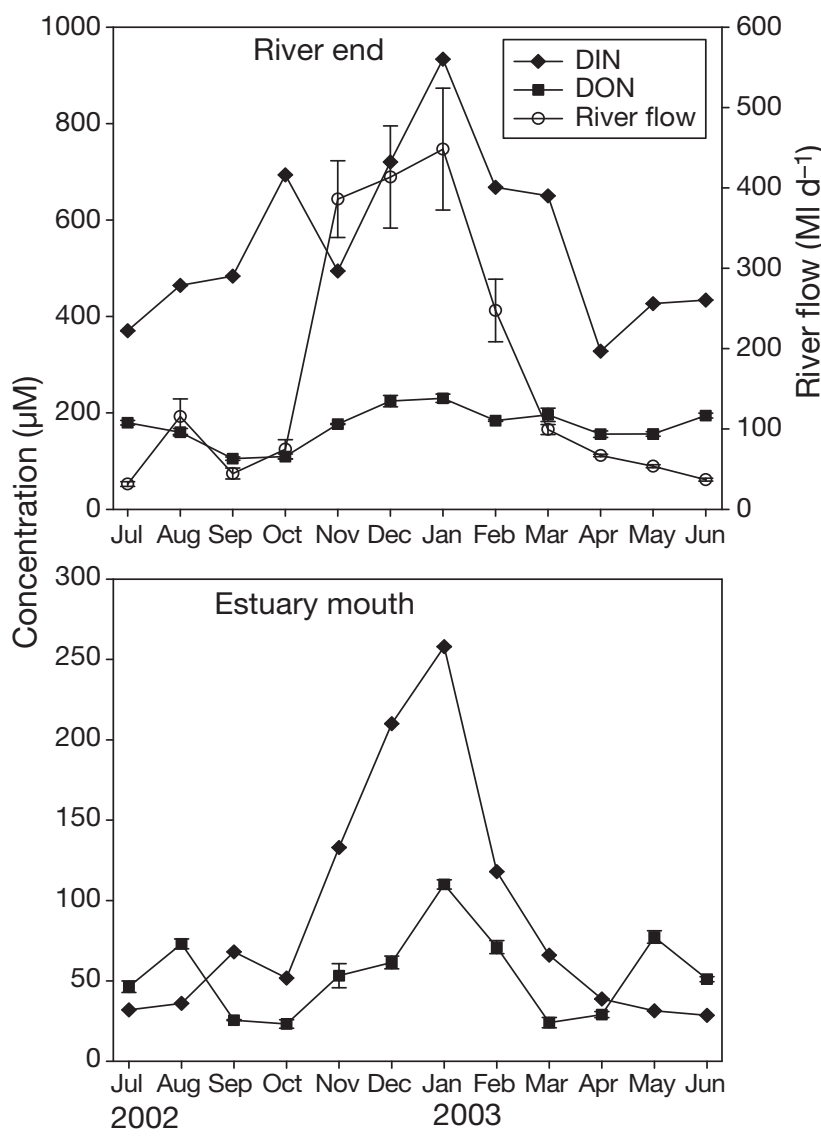

Fig. 4. Seasonal variation of DON and DIN concentrations at the top and bottom of the Colne estuary, and river flow (bars indicate $\mathrm{SE}, \mathrm{n}=3$ )

DON degradation within the water column, in the absence of sediment, was extremely slow (only 0.001 to $0.005 \mathrm{~d}^{-1}$ of the DON removed), while in the presence of sediment 0.016 to $0.060 \mathrm{~d}^{-1}$ of the DON in the water was removed. Therefore, the major sink for DON dur-

Table 2. Rates of dark removal of DON from water-only controls and sediment + water core tubes at 3 sites along the Colne estuary. Data are mean first-order rate constant $( \pm \mathrm{SE}, \mathrm{n}=3)$; units are proportion of DON removed $\mathrm{d}^{-1}$

\begin{tabular}{|lll|}
\hline Month & Water-only controls & Sediment + water \\
\hline Hythe (Top) & & \\
Jan & $-0.0135 \pm 0.0079$ & $-0.0600 \pm 0.0093$ \\
Apr & $-0.0034 \pm 0.0047$ & $-0.0157 \pm 0.0044$ \\
Jun & $-0.0015 \pm 0.0025$ & $-0.0372 \pm 0.0110$ \\
Wivenhoe (Middle) & \\
Apr & $-0.0021 \pm 0.0093$ & $-0.0225 \pm 0.0008$ \\
Jun & $-0.0047 \pm 0.0009$ & $-0.0169 \pm 0.0109$ \\
Brightlingsea (Mouth) & \\
Apr & $-0.0023 \pm 0.0096$ & $-0.0293 \pm 0.0074$ \\
Jun & $-0.0012 \pm 0.0096$ & $-0.0300 \pm 0.0087$ \\
Mean values & -0.0041 & -0.0303 \\
\hline
\end{tabular}

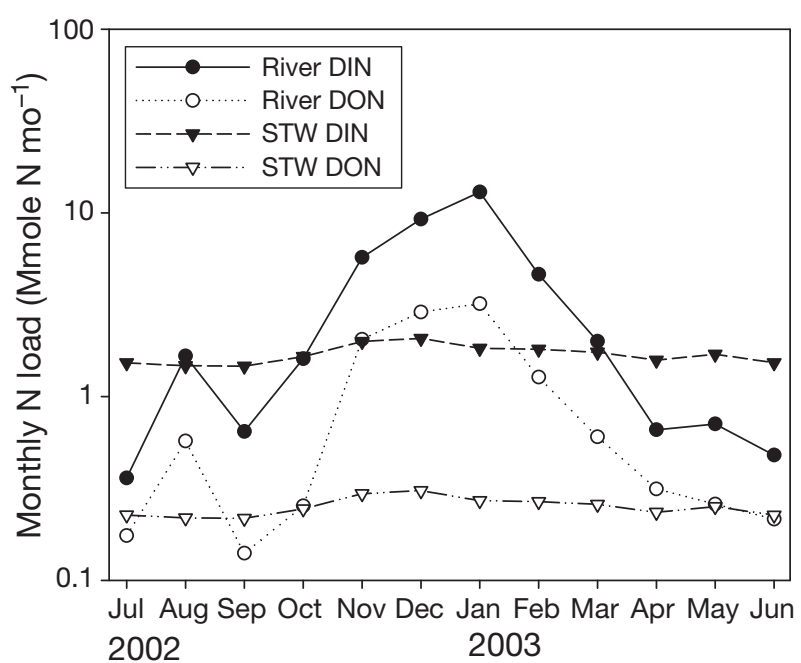

Fig 5. Monthly loads of DIN and DON to the Colne estuary from the river and the Colchester sewage treatment works

ing the experiments was exchange from the water into the bottom sediments.

\section{DON concentration}

Ultrafiltration increased the DON concentration 10 -fold compared to the initial concentration, and retention of DON in the concentrate was $>90 \%$ of that initially present in the water. Simultaneously, $>99 \%$ of DIN (as $\mathrm{NO}_{3}{ }^{-}, \mathrm{NO}_{2}{ }^{-}$and $\mathrm{NH}_{4}{ }^{+}$) was removed. Strictly, urea is not a component of DON, as it contains no carbon-carbon bonds, but some papers (e.g. Wiegner et al. 2006) have included it in the DON fraction, although we do not. Urea, amino acids and short polypeptides would have been removed during ultrafiltration, but the high recovery of the initial DON in the concentrate indicated that these were only a very small component relative to DON with $M_{r}>500$ Da.

\section{Bioassay of DON}

The biomass production (as expressed by turbidity as an index of biomass) of Pseudomonas aeruginosa to available $\mathrm{N}$ was linear over the range of 0 to $20 \mu \mathrm{mol} \mathrm{N}$ flask $^{-1}$ and became asymptotic at $>50 \mu \mathrm{mol} \mathrm{N}$ flask $^{-1}$. Maximum biomass (turbidity) was achieved within $24 \mathrm{~h}$ in standards where $\mathrm{N}$ was present as $\mathrm{NH}_{4}{ }^{+}$, but it took longer to reach maximum biomass when growing on DON concentrate, often not plateauing out until after 5 to $6 \mathrm{~d}$. The maximum turbidity attained in an assay flask was that used to estimate its available $\mathrm{N}$ from the standard curve. 
Table 3. Percentage bioavailability of DON concentrates (date sampled shown in brackets). STW: sewage treatment works

\begin{tabular}{|c|c|c|}
\hline \multicolumn{3}{|c|}{$\begin{array}{c}\% \text { of DON } \\
\text { bioavailable } \\
(\text { mean } \pm \mathrm{SE}, \mathrm{n}=3)\end{array}$} \\
\hline Hythe (Jan 2004) & $4.7 \pm 0.17$ & \multirow{4}{*}{ Mean $4.6( \pm 0.16, \mathrm{n}=12)$} \\
\hline Hythe (Jan 2004) & $4.7 \pm 0.15$ & \\
\hline Hythe (Mar 2004) & $4.9 \pm 0.15$ & \\
\hline Hythe (Mar 2004) & $4.2 \pm 0.12$ & \\
\hline River (Mar 2004) & $5.2 \pm 0.17$ & \multirow{2}{*}{ Mean $4.7( \pm 0.54, \mathrm{n}=6)$} \\
\hline River (Mar 2004) & $4.1 \pm 0.11$ & \\
\hline STW (Mar 2004) & $3.5 \pm 0.08$ & \multirow{3}{*}{ Mean $2.9( \pm 0.38, \mathrm{n}=9)$} \\
\hline STW (Mar 2004) & $3.0 \pm 0.08$ & \\
\hline STW (Mar 2004) & $2.2 \pm 0.05$ & \\
\hline
\end{tabular}

Measurements of OD over $8 \mathrm{~d}$ showed that growth of Pseudomonas aeruginosa was exponential, giving linear plots of the ln OD against time, without lag at the Hythe and STW, but sometimes a short lag with DON samples from the river. From the standards, the OD values were converted into available $\mathrm{N}$ in $\mathrm{DON}_{\text {; }}$ we then plotted the natural log of the percentage of DON remaining against time. Linear regression gave mean $( \pm \mathrm{SE}$ ) first-order decay constants during the bioassays of $-0.0085( \pm 0.0004) \mathrm{d}^{-1}$ for the river DON, -0.0031 $( \pm 0.0008) \mathrm{d}^{-1}$ for the STW DON, and $-0.0061( \pm 0.0006)$ $\mathrm{d}^{-1}$ for the Hythe DON $\left(\mathrm{r}^{2}\right.$ values of 0.98 [Hythe and Weir] and 0.99 [STW]; $p<0.05$ in all cases). The decomposition curves showed that only a small proportion of the DON was rapidly degraded, and most of the DON in the concentrate was resistant to decomposition. The relatively rapid phase of decomposition of DON concentrate in the assays consumed from 2.9 to $4.7 \%$ of the DON concentrate in the first $8 \mathrm{~d}$, and this phase was distinct at all 3 sites. Table 3 shows the results of these bioassays as the \% of DON that was bioavailable. The \% bioavailability of DON in the STW effluent was significantly lower (ANOVA of arcsine transformed data, $\mathrm{p}<0.05$ ) than at the other 2 sites.

\section{DISCUSSION}

The modification of the Kjeldahl digestion (Fraga 1959, Doval et al. 1997) measures DON directly as ammonium after digestion, which removes background DIN. Our initial work confirmed that even in the high nutrient estuarine waters of the Colne, the technique of Doval et al. (1997) was an effective and reproducible direct method of DON analysis. Doval et al. (1997) showed that recoveries from this modified method were similar to, or better than, recoveries with other methods (persulphate oxidation, UV oxidation, high temperature combustion).
The current interest in DON originated from data suggesting that it could be a significant proportion of the total $\mathrm{N}$ load through estuaries, and could be used by phytoplankton and bacteria as an $\mathrm{N}$ source. For example, Seitzinger \& Sanders (1997) reported that in terms of concentrations, DON ranged between 20 and $>90 \%$ of TDN in some estuaries, but in anthropogenically nutrient-enriched rivers and estuaries, DON is likely to represent a proportionately lesser component. Our data showed that in the highly nutrified Colne estuary, DON was at relatively high concentrations compared to coastal seawater, but was only a relatively small component ( $23 \%$ on an annual basis) of the TDN load into the estuary. Similarly, in the nearby River Great Ouse, DON was only 3 to $20 \%$ of TDN (Rendell et al. 1997). In contrast, in oligotrophic estuaries draining relatively pristine catchments (Wiegner et al. 2006) or in low tidal estuaries (Sundbäck et al. 2006), DON may be a much greater proportion of the TDN load and might therefore assume much greater ecological importance. DON can contribute significantly to marine eutrophication (Berman 1997, Seitzinger \& Sanders 1997, Hasegawa et al. 2000), particularly as it is now realised that even large molecular weight DON may be biologically available (Amon \& Benner 1994, Carlson et al. 1995, Bushaw-Newton \& Moran 1999). As both DIN and DON concentrations declined down the Colne estuary, the proportion of DON in the total $\mathrm{N}$ increased (Fig. 2), which suggested either that DON was refractory (e.g. Mortazavi et al. 2001) and was removed more slowly than DIN along the estuary, or that there were other sources of DON along the estuary.

There appeared to be more than one source of DON in the upper estuary of the Colne, as the DON-salinity plots were usually linear over the salinity range 0 to 30 , but sometimes a decrease in DON concentration occurred at salinity values $\leq 5$. River end-member concentrations derived from the plots were then greater than the measured river DON concentrations (e.g. nitrate in June 2003, see Fig. 3). Mortazavi et al. (2001) have previously attributed similar plots with end-member DON concentrations greater than riverine DON concentration to input of phytoplanktonderived DON within the estuary. However, primary production in the Colne estuary is low (Kocum et al. 2002b) and light-limited, within the range suggested as oligotrophic by Nixon (1995) despite the high nutrient concentrations. Rather, any inflection in the DON:salinity plot was presumably the result of inputs of DON in effluent from the Colchester STW, situated at the Hythe (Site 4) in the upper estuary elevating the DON concentrations in the estuary below the point of STW input. The linearity of the DON:salinity plots in the Colne below the point of inflection (when 
present) suggested that a decrease of DON concentrations was largely due to dilution with low DON seawater, and there were no major sources or sinks of DON lower down the estuary. Others (Gardner \& Stephens 1978, Mantoura \& Woodward 1983) have also reported that dissolved organic matter passing through estuaries is refractory. In contrast, the slopes of plots of $\mathrm{NO}_{3}{ }^{-}$:salinity were also statistically linear but with a greater value of slope, indicating faster dilution than DON along the estuary. We have previously shown (Ogilvie et al. 1997) that benthic denitrification removes about $50 \%$ of the nitrate load within the Colne estuary, but the conventional downward convex plot indicating removal of nitrate (e.g. Officer 1979) was not observed. We therefore need to consider the relative importance of DON loads from each of these sources, and from elsewhere along the estuary, and their biological availability.

While there were only slight seasonal changes of DON concentration in the upper Colne estuary, there were distinct seasonal changes in concentrations of both DIN and DON at the estuary mouth, decreasing during summer. A seasonal cycle is more likely to be apparent where the ambient concentrations (of both DIN and DON) are low, as in the coastal seawater, and seasonal change occurs against a low concentration background, as reported in other coastal seas (Butler et al. 1979, Bronk \& Glibert 1993, Jørgensen et al. 1999). It has been suggested previously (Bode et al. 2004) that declines in DON and DIN during summer are due to their removal by plankton. However, the extent of any seasonal signal of nitrate (and DON) in the upper estuary may also vary interannually, probably depending upon variation in rainfall patterns, as Ogilvie et al. (1997) reported a distinct seasonal peak of nitrate concentration in the upper Colne estuary during early winter of 1993-4, in contrast to our present study. As DIN loads in these rivers are strongly influenced by rainfall, the extent of any winter peak will depend on the annual rainfall pattern (Van Beusekom \& De Jonge 1998, Nedwell et al. 1999), and may vary significantly from year to year. Colne River flow during November and December was much greater during 2002 than 2003, but that in January and February was greater in 2003 than 2002 (National River Flow Archive).

Table 1 shows that the river contributed $62 \%$ of the total $\mathrm{N}$ load to the estuary on an annual basis. However, much of the river load was in the winter (see Fig. 5) when biological activity in the estuary is low (Kocum et al. 2002b). During the summer, the input from the STW was greater than that from the river. Previously, Robinson et al. (1998) also inferred that the STW was the dominant source of estuarine $\mathrm{N}$ during the summer, contributing $>70 \%$ of the $\mathrm{N}$ load.
Sediments can either be sources or sinks of DON in estuarine water. DON effluxes greater than DIN efflux from sediment have been reported (Lomstein et al. 1998, Tyler et al. 2001, Anderson et al. 2003, Sundbäck et al. 2004), although others noted small or insignificant efflux of DON from sediments (Burdige \& Zheng 1998, Mortazavi et al. 2001), or DON fluxes from the water column into the bottom sediments (Cowan \& Boynton 1996, Hopkinson et al. 1999). Sundbäck et al. (2004) reported uptake of DON in shallow sediments, but release by deeper sediments. Our results showed consistent but slow reduction with time of DON from the water overlying the sediment cores, the slope of the plots giving first-order rate constants of between -0.014 and $-0.06 \mathrm{~d}^{-1}$. This removal, in the presence of sediment, might be due to DON degradation in the water column or slow exchange of DON into the sediment. However, in the water-only controls, the firstorder rate constants for DON removal in the water were extremely low (Table 2), confirming very slow turnover of DON in the water column and the bottom sediments being the major sites of DON removal, as reported by other studies (Cowan \& Boynton 1996, Burdige \& Zheng 1998, Hopkinson et al. 1999). While primary production might also add DON to the water column, this will not be the case during the experimental dark incubations, so that the rate constants measured in the water-only controls will include degradation of all components of DON, including any phytoplankton-derived DON present in the water column and small $\mathrm{M}_{\mathrm{r}}$ components such as urea and amino-acids.

The bioassays gave reproducible results, with only between 2.2 and $5.2 \%$ of the DON of $\mathrm{Mr}>500 \mathrm{Da}$ being available to Pseudomonas aeruginosa. The use of a single, metabolically extremely diverse assay organism permits calibrated, reproducible and hence comparable measurements of the available DON between different sites, as opposed to measurements with variable 'natural' communities, which makes any intercomparisons of data problematic. $P$. aeruginosa is a ubiquitous organism widely distributed in marine, estuarine, freshwater, soil and animal environments (e.g. Khan et al. 2008), and is therefore a good candidate for such bioassay.

The concentration of DON by ultrafiltration was effective, retaining $>90 \%$ of the initial DON $>500$ Da while removing $>98 \%$ of the initial DIN present. Residual nitrate after concentration was $<6 \mu$ mol $\mathrm{N}$ $100 \mathrm{ml}^{-1}$ concentrate and from the calibration curve of growth of Pseudomonas aeruginosa would have generated, at most, $<10 \%$ of the OD attained in the bioassays. Therefore, at a minimum, $>90 \%$ of the bacterial growth must have been due to use of available DON. Clearly, the calculated percentage of DON 
bioavailable in the concentrate did not include the small <500 Da $M_{r}$ molecules such as amino acids and small polypeptides, which were removed along with DIN during the concentration process, but this was only a very small proportion of the total DON and cannot change the conclusion that the major part of the DON was refractory. The bioassay data also corroborated the very slow removal of DON during the core tube experiments, which would have also included any removal of DON with $\mathrm{M}_{\mathrm{r}}<500$ Da. 'Bioavailability' is a time-related and methodologically defined construct, as what is 'available' changes as labile DON is metabolised, and microbial hydrolytic activity makes available that which was previously unavailable DON. The longer the assay period, therefore, the greater is likely to be the proportion of available DON reported (Bastviken et al. 2004), although the rate at which it becomes available may decline as residual DON becomes increasingly refractory. Environmental factors such as UV photo-oxidation also may increase the rate at which hitherto refractory DON becomes bioavailable (Karl \& Bjorkman 2002, Boyer et al. 2004), although this factor may be small in highly turbid estuaries such as the Colne where light penetration is restricted (Kocum et al. 2002b). Alternating cycles of photo-oxidation and microbial activity also have been reported to increase rates of dissolved organic matter degradation several-fold over biological activity alone (Miller \& Moran 1997). Our technique where DON is removed, concentrated and bioassayed is likely to result in much more of a 'snapshot' of available DON at one time, rather than a measure of available DON integrated over a period of incubation, as used by others (e.g. Seitzinger \& Sanders 1997).

Overall, only minor proportions of DON with $M_{r}$ $>500$ Da from all 3 sites were bioavailable, while the bulk was refractory (Table 3 ). The proportion of DON bioavailable was significantly $(p<0.05)$ lower in the STW effluent than in the river or estuary DON, commensurate with microbiological removal in the STW process leaving only highly refractory material. While we have used a different approach to measuring bioavailable DON than have other workers, and the exact composition of DON may vary from site to site, our data compare to those of Boyer et al. (2004) who reported 3.5 to $9.2 \%$ bioavailability of DON over $16 \mathrm{~d}$ at 3 sites in Florida Bay, USA, whereas Stepanauskas et al. (1999) reported 2 to $16 \%$ bioavailability of DON from Swedish wetlands. However, other workers have reported much higher percentages of bioavailability in other environments with other methods (Wiegner et al. 2006). Seitzinger \& Sanders (1997) reported 40 to $72 \%$ DON available over $23 \mathrm{~d}$ in the Delaware and Hudson estuaries, USA, using changes in microbial numbers and DIN and DON pools.
Seitzinger et al. (2002) reported 0 to $73 \%$ of DON available in estuarine DON based on bacterial production measured by thymidine incorporation in a natural mixed microbial community. However, the calculation with ${ }^{3} \mathrm{H}$-thymidine incorporation of production values in natural mixed communities, with all of the assumptions inherent in these calculations, remains problematic.

Our experiments show that although DON represents a significant proportion (19\%) of the total $\mathrm{N}$ load to the estuary, the fraction of that DON that is bioavailable is small and is unlikely to represent a significant nutrification/eutrophication pressure in the estuary. From an annual total river+STW DON load of 16.2 $\mathrm{Mmol} \mathrm{N} \mathrm{yr}^{-1}$, only $0.75 \mathrm{Mmol} \mathrm{N} \mathrm{yr}^{-1}$ is apparently immediately bioavailable. In contrast, $68.2 \mathrm{Mmol} \mathrm{N} \mathrm{yr}^{-1}$ is immediately available as DIN. The actual amount of DON that is degraded within the estuary, and hence becomes available, is dependent upon the DON degradation rate compared to the residence time of water in the estuary. The freshwater flushing time (FWFT) of the Colne ranges from 5 to $14 \mathrm{~d}$ (A. Sage unpubl. data), and using a mean DON first-order degradation rate of $0.03 \mathrm{~d}^{-1}$ and $6 \mathrm{~d}$ FWFT, $2.5 \mathrm{Mmol} \mathrm{N} \mathrm{yr}^{-1}$ (15.4\% of DON input) will be bioavailable within the estuary. This is equivalent to only $2.5 / 84.4=2.9 \%$ of the estuarine DIN load. While experimentally, the removal of DON was faster in the presence of sediment than in the water column alone (Table 2), the influence of the sediments will lessen as the water column above the sediment becomes deeper, and the net removal of DON in the estuary may actually be significantly less than the estimate above if the overall estuary rate constant for degradation is nearer to that in the water column. Consequently, our calculation of DON available within the estuary is conservative. Clearly, the majority of the DON load may eventually become bioavailable as it is slowly broken down, but that is likely to occur well outside the estuary, in the coastal zone. Similarly, Kocum et al. (2002a) also concluded that depletion of DIN and imposition of nutrient-limitation on algal growth would only occur outside the estuary. Photo-oxidation may increase the rate at which DON decays, although photooxidation is likely to be restricted in the turbid Colne estuary, but even as much as a 5-fold increase in degradation rate due to photo-oxidation cannot change the conclusion that DON is not a significant source of available $\mathrm{N}$ within this estuary. Mortazavi et al. (2001) also reported that DON retention within the Apalachicola Bay, Florida, USA, was insignificant because of a short turn-over time in the bay. However, DON may be much more significant as a source of $\mathrm{N}$ in pristine estuaries with low nutrient loads, and where long flushing times optimise the breakdown of refractory DON to available $\mathrm{N}$ within an estuary. 
Acknowledgements. We thank Anglian Water PLC for their assistance with effluent flow data for the Colchester sewage treatment works, and several anonymous reviewers whose comments improved an earlier version of the manuscript.

\section{LITERATURE CITED}

Agedah E (2005) Loads, sources and bioavailability of dissolved organic nitrogen in the Colne estuary, South East England, United Kingdom. PhD thesis, University of Essex, Colchester

Amon RMW, Benner R (1994) Rapid cycling of high molecular weight dissolved organic matter in the ocean. Nature 369: 549-552

Anderson IC, McGlathery KJ, Tyler AC (2003) Microbial mediation of 'reactive' nitrogen. Mar Ecol Prog Ser 246: 73-84

Bastviken D, Persson L, Odham G, Tranvik L (2004) Degradation of dissolved organic matter in oxic and anoxic lake water. Limnol Oceanogr 49:109-116

Benner R, Pakulski JD, McCarthy M, Hedges J, Hatcher PJ (1992) Bulk chemical characteristics of dissolved organic matter in the oceans. Science 255:1561-1564

Berman T (1997) Dissolved organic nitrogen utilization by an Aphanizomenon bloom in Lake Kinneret. J Plankton Res 19:577-586

Bode A, Varela MT, Teira E, Fernandez E, Gonzalez N, Varela M (2004) Planktonic carbon and nitrogen cycling off northwest Spain: variations in production of particulate and dissolved organic pools. Aquat Microb Ecol 37:95-107

Boyer JN, Jaffe R, Daily SK, Maie N (2004) Biological availability of organic nitrogen in Florida Bay. Final Report to South Florida Water Management District. C-C20306A. Southeast Environmental Research Center, Florida International University, Miami, FL

$>$ Bronk DA, Glibert PM (1993) Application of $15 \mathrm{~N}$ tracer method to the study of dissolved organic nitrogen uptake during spring and summer in Chesapeake Bay. Mar Biol 115:501-508

Buffam I, Galloway JN, Blum LK, McGlathery KJ (2001) A stormflow/baseflow comparison of dissolved organic matter concentrations and bioavailability in an Appalachian stream. Biogeochemistry 53:269-306

Burdige DJ, Zheng S (1998) The biochemical cycling of dissolved organic nitrogen in estuarine sediments. Limnol Oceanogr 43:1796-1813

Bushaw-Newton KL, Moran MA (1999) Photochemical formation of biologically available nitrogen from dissolved humic substances in coastal marine systems. Aquat Microb Ecol 18:285-292

Butler EI, Knox S, Liddi-Coat F (1979) The relationship between inorganic and organic nutrients in sea water. J Mar Biol Assoc UK 59:239-250

> Carlsson P, Graneli E, Tester P, Boni L (1995) Influences of riverine humic substances on bacteria, protozoa, phytoplankton and copepods in a coastal plankton community. Mar Ecol Prog Ser 127:213-221

Collos Y, Yin K, Harrison PJ (1992) A note of caution on reduction conditions when using the copper-cadmium column for nitrate determinations in aquatic environments of varying salinities. Mar Chem 38:325-329

Cowan JL, Boynton RW (1996) Sediment water oxygen and nutrient exchanges along the longitudinal axis of Chesapeake Bay: seasonal patterns, controlling factors and ecological significance. Estuaries 19:562-580
De Jonge VN, Elliott M, Orive E (2002) Causes, historical development, effects and future challenges of a common environmental problem: eutrophication. Hydrobiologia 475-476:1-19

Doval MD, Fraga F, Perez FF (1997) Determination of dissolved organic nitrogen in seawater using Kjeldahl digestion after inorganic nitrogen removal. Oceanol Acta 20: $713-720$

Fraga F (1959) Determinacion de nitrogeno organico suspendido y disuelto en el agua de mar. Invest Pesq 14: $121-127$

Gardner WS, Stephens JA (1978) Stability and composition of terrestrially-derived dissolved organic nitrogen in continental shelf surface waters. Mar Chem 6:335-342

Harwood JE, Kuhn AL (1970) A colorimetric method for ammonia in natural waters. Water Res 4:805-811

Hasegawa T, Koike I, Mukai H (2000) Dissolved organic matter dynamics in coastal waters and effect of copepods. J Exp Mar Biol Ecol 244:219-238

Hessen DO (1999) Catchment properties and the transport of major elements to estuaries. In: Nedwell DB, Raffaelli DG (eds) Advances in ecological research, Vol 29. Academic Press, London, p 1-41

Hopkinson CS, Giblin AE, Tucker J, Garritt RH (1999) Benthic metabolism and nutrient cycling along an estuarine salinity gradient. Estuaries 22:863-881

Howarth RW (2004) Human acceleration of the nitrogen cycle: drivers, consequences, and steps toward solutions. Water Sci Technol 49:7-13

Jørgensen NO, Transvik LJ, Berg GM (1999) Occurrence and bacteria cycling of dissolved organic nitrogen in the Gulf of Riga, the Baltic Sea. Mar Ecol Prog Ser 191:1-18

Karl DM, Björkman KM (2002) Dynamics of DOP. In: Hansell DA, Carlson CA (eds) Biogeochemistry of marine dissolved organic matter. Academic Press, San Diego, CA, p 250-267

> Khan NH, Ahsan M, Yoshizawa S, Hosoya S, Yokota A, Kogure K (2008) Multilocus sequence typing and phylogenetic analyses of Pseudomonas aeruginosa isolates from the ocean. Appl Environ Microbiol 74:6194-6205

Kocum E, Nedwell DB, Underwood GJC (2002a) Regulation of phytoplankton primary production along a hypernutrified estuary. Mar Ecol Prog Ser 231:13-22

> Kocum E, Underwood GJC, Nedwell DB (2002b) Simultaneous measurement of phytoplanktonic primary production, nutrient and light availability along a turbid, eutrophic UK east coast estuary (the Colne Estuary). Mar Ecol Prog Ser 231:1-12

- Krom MJD (1980) Spectrophotometric determination of ammonia: a study of a modified Berthelot reaction using salicylate and dichloroisocyanurate. Analyst (Lond) 105: 305-317

> Lomstein BA, Jensen AGU, Hansen JW, Andreasen JB, Hansen LS, Berntsen J, Kunzendorf H (1998) Budgets of sediment carbon and nitrogen cycling in the shallow water of Knebel Vig, Denmark. Aquat Microb Ecol 14: 69-80

Mantoura RFC, Woodward EMS (1983) Conservative behaviour of riverine dissolved organic-carbon in the Severn estuary - chemical and geochemical implications. Geochim Cosmochim Acta 47:1293-1309

Miller WL, Moran MA (1997) Interaction of photochemical and microbial processes in the degradation of refractory dissolved organic matter from coastal marine environments. Limnol Oceanogr 42:1317-1324

> Mortazavi B, Iverson RL, Huang W (2001) Dissolved organic nitrogen and nitrate in Apalachicola Bay, Florida: spatial distributions and monthly budgets. Mar Ecol Prog Ser 214: 79-91 
Nedwell DB (1987) Distribution and pool sizes of microbially available carbon in sediment measured by a microbiological assay. FEMS Microbiol Ecol 45:47-52

Nedwell DB, Jickells T, Trimmer MT, Sanders R (1999) Nutrients in estuaries. In: Nedwell DB, Raffaelli D (eds) Estuaries. Academic Press, London, p. 43-92

> Nedwell DB, Dong LF, Sage A, Underwood GJC (2002) Variations of the nutrient loads to the mainland UK estuaries: correlations with catchment areas, urbanisation and coastal eutrophication. Estuar Coast Shelf Sci 54: 951-970

Nixon SW (1995) Coastal marine eutrophication: a definition, social causes and future concerns. Ophelia 41:199-219

Officer CB (1979) Discussion of the behaviour of non-conservative dissolved constituents in estuaries. Estuar Coast Shelf Sci 9:91-94

> Ogilvie B, Nedwell DB, Harrison RM, Robinson A, Sage A (1997) High nitrate, muddy estuaries as nitrogen sinks: the nitrogen budget of the River Colne estuary (United Kingdom). Mar Ecol Prog Ser 150:217-228

Perakis SS, Hedin LO (2002) Nitrogen loss from unpolluted South American forests mainly via dissolved organic compounds. Nature 415:416-419

Rendell AR, Horrobin TM, Jickells TD, Edmunds HM, Brown J, Malcolm SJ (1997) Nutrient cycling in the Great Ouse estuary and its impact on nutrient fluxes to The Wash, England. Estuar Coast Shelf Sci 45:653-668

Seitzinger SP, Sanders RW (1997) Contribution of dissolved organic nitrogen from rivers to estuarine eutrophication. Mar Ecol Prog Ser 159:1-12

Seitzinger SP, Sanders RW, Styles R (2002) Bioavailability of DON from natural and anthropogenic sources to estuarine plankton. Limnol Oceanogr 47:353-366

Stedmon CA, Markager S, Sondergaard M, Vang T, Laubel A, Borch NH, Windelin S (2006) Dissolved organic matter (DOM) export to a temperate estuary: seasonal variations

Editorial responsibility: Matthias Seaman, Oldendorf/Luhe, Germany and implications of land use. Estuar Coasts 29:388-400

Stepanauskas R, Leonardson L, Tranvik LJ (1999) Bioavailability of wetland-derived DON to freshwater and marine bacterioplankton. Limnol Oceanogr 44:1298-1307

Strickland JDH, Parsons TR (1972) A practical handbook of seawater analysis, 2nd edn, Vol 167. Fisheries Research Board of Canada

Sundbäck K, Linares F, Larson L, Wulff A (2004) Benthic nitrogen fluxes along a depth gradient in a microtidal fjord: the role of denitrification and microphytobenthos. Limnol Oceanogr 49:1095-1107

Sundbäck K, Miles A, Linares F (2006) Nitrogen dynamics in non-tidal littoral sediments: the role of microphytobenthos and denitrification. Estuar Coasts 29:1196-1211

Tyler AC, McGlathery KJ, Anderson IC (2001) Macroalgae mediation of dissolved organic nitrogen fluxes in a temperate coastal lagoon. Estuar Coast Shelf Sci 53:155-168

> Van Beusekom JEE, De Jonge VN (1998) Retention of phosphorus and nitrogen in the Ems estuary. Estuaries 21: $527-539$

Veuger B, Middelburg JJ, Boschker HTS, Nieuwenhuize J, van Rijswijk P, Rochelle-Newall EJ, Navarro N (2004) Microbial uptake of dissolved organic and inorganic nitrogen in Randers Fjord. Estuar Coast Shelf Sci 61:507-515

Vitousek PM, Aber J, Howarth RW, Likens GE and others (1997) Human alteration of the global nitrogen cycle: sources and consequences. Ecol Appl 7:737-750

Ward AK, Wetzel RG (1984) Molecular weight fractionation of dissolved organic nitrogen and carbon compounds from two lakes of differing eutrophic status. Arch Hydrobiol 101:481-488

> Wiegner TN, Seitzinger SP, Glibert PM, Bronk DA (2006) Bioavailability of dissolved organic nitrogen and carbon from nine rivers in the eastern United States. Aquat Microb Ecol 43:277-287

Submitted: August 13, 2008; Accepted: January 22, 2009 Proofs received from author(s): April 22, 2009 